\title{
NO EVIDENCE FOR A POINT MUTATION AT CODON 713 AND 717 OF AMYLOID PRECURSOR PROTEIN GENE IN JAPANESE SCHIZOPHRENICS
}

\author{
Rimmei Fukuda, ${ }^{1}$ Mineko Hattori, ${ }^{1}$ Tsukasa SAsaki, ${ }^{1}$ \\ Hajime Kazamatsuri, ${ }^{1}$ Shoji Kuwata, ${ }^{2}$ Yoichi Shibata, ${ }^{2}$ \\ and Shinichiro NANKO ${ }^{1, *}$ \\ ${ }^{1}$ Department of Psychiatry, Teikyo University School of Medicine, \\ Kaga 2 chome, Itabashi-ku, Tokyo 173, Japan \\ ${ }^{2}$ Department of Transfusion Medicine and Immunohematology, \\ Faculty of Medicine, University of Tokyo. \\ Hongo, Bunkyo-ku, Tokyo 113, Japan
}

\begin{abstract}
Summary A point mutation at codon 717 of amyloid precursor protein (APP) gene has been demonstrated to play an important pathogenic role in some cases of familial Alzheimer's disease (FAD). Recently, a single case of chronic schizophrenia with a point mutation at codon 713 of APP gene which sits very close to the mutation in FAD was reported. We screened for these two kinds of mutations in 39 schizophrenic patients using polymerase chain reaction (PCR) and restriction enzyme technique. A mutation of codon 713 creates a MaelII restriction site and that of codon 717 creates a $B c l I$ site. Enzyme digestion with amplified PCR product revealed no restriction site in all subjects. None of our subjects had either of these two kinds of mutations. Our findings support the hypothesis that the case of a mutation at codon 713 of APP gene is a natural non-pathogenic variant and, as well as a mutation at codon 717 , has no relation with the genetic predisposition to schizophrenia.
\end{abstract}

Key Words schizophrenia, amyloid precursor protein gene, point mutation

\section{INTRODUCTION}

Mutations at codon 717 in exon 17 of the amyloid precursor protein (APP) gene which is located on chromosome 21 have been previously shown to segregate with early-onset Alzheimer's disease in several families (Goate et al., 1991; Naruse

Received July 26, 1993; Revised version accepted September 9, 1993.

*To whom correspondence should be addressed. 
et al., 1991; Murrel et al., 1992; Chartier-Harlin et al., 1992). Following reports showed the evidence for other kinds of mutations in exon 16 or 17 of APP gene segregating with some types of familial Alzheimer's disease (FAD) (Hendriks et al., 1992; Mullan et al., 1992; Balbin et al., 1992). Thus implications of mutation in APP gene and presumable unusual metabolic pathway of APP are now in the spotlight for the pathogenesis of a proportion of cases with FAD.

Jones et al. (1992) reported a single case of chronic schizophrenia with a C to $\mathrm{T}$ nucleotide substitution which yields an alanine to valine change at codon 713 , just four codons removed from the cluster of the FAD mutations. It is interesting because some subtypes of schizophrenia progressively lead to intellectual deterioration, formerly called as "dementia praecox." Mant et al. (1992) recently reported that they failed to detect any abnormality in APP gene among schizophrenic families including a total of 191 individuals by the use of linkage analysis and single strand conformation polymorphism (SSCP) analysis.

To re-evaluate the correlation between a point mutation on APP gene and schizophrenia, we investigated whether a $\mathrm{C}$ to $\mathrm{T}$ nucleotide substitution which results in an alanine to valine change at codon 713 reported by Jones et al. (1992) or a $\mathrm{G}$ to $\mathrm{A}$ substitution which results in a valine to isoleucine change at codon 717 reported by Goate et al. (1991) might be present in 39 unrelated Japanese schizophrenics using PCR and restriction enzyme technique.

\section{SUBJECTS AND METHODS}

Thirty-nine unrelated schizophrenics diagnosed according to DSM-III-R were recruited from inpatients and outpatients of Department of Psychiatry, Teikyo University Hospital. Subjects consists of 20 males aged $33.6 \pm 11.9$ years (mean \pm S.D.) and 19 females aged $40.0 \pm 11.7$ years (mean \pm S.D.). Oral and written informed consents were obtained from all subjects.

Genomic DNA was isolated from peripheral white blood cells using standard phenol/chloroform methods. We obtained 319 bp product of exon 17 of the APP gene after the PCR amplification of genomic DNA using the oligonucleotide primer set which is identical with that of Jones et al. (1992): 5'-CCTCATCCAAATGTCCCCGTCATT- $3^{\prime}$ and 5'-GCCTAATTCTCTCATAGTCTTAACCCAC-3'.

Mutation at codon 713 creates a MaeIII restriction site (/GTnAC) yielding fragments of $189 \mathrm{bp}$ and $130 \mathrm{bp}$, and mutation at codon 717 creates a $B c l$ I restriction site (T/GATCA) yielding fragments of $199 \mathrm{bp}$ and $120 \mathrm{bp}$, while wild-type DNA remains uncut.

We digested PCR product of exon 17 of the APP gene with MaeIII or BclI according to manufacturer's recommendations. Following exposure to the restriction enzyme, the DNA was electrophoresed in $10 \%$ polyacrylamide gels. $\phi \mathrm{X} 174 /$ HaeIII digest was used as a size marker. The polyacrylamide gels were stained with ethidium bromide and DNA fragments were visualized using a UV-transil- 
luminator.

\section{RESULTS}

As shown in Fig. 1 and Fig. 2, none of the PCR products of subjects' DNA was cut after the MaeIII or BclI digestion. No evidence for a $\mathrm{C}$ to $\mathrm{T}$ nucleotide substitution at codon 713 or a $\mathrm{G}$ to $\mathrm{A}$ at 717 was detected.

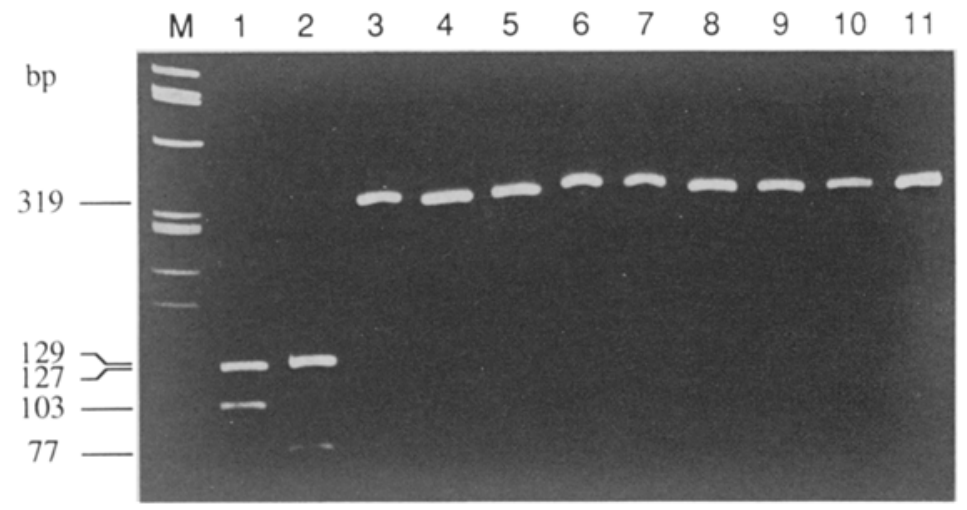

Fig. 1. Polyacrylamide gel analysis of amplified exon 17 after digestion with MaeIII. Lane 1 and lane 2, PCR products of exon 2 of human leukocyte antigen DRB1 gene which contain a MaeIII site as a positive control for the restriction enzyme reaction; from lane 3 to lane 11, samples from schizophrenic subjects. DNA from 39 unrelated schizophrenics remains uncut. $\phi$ X174/MaeIII digest was used as a marker to estimate fragment size (lane $\mathrm{M}$ ).

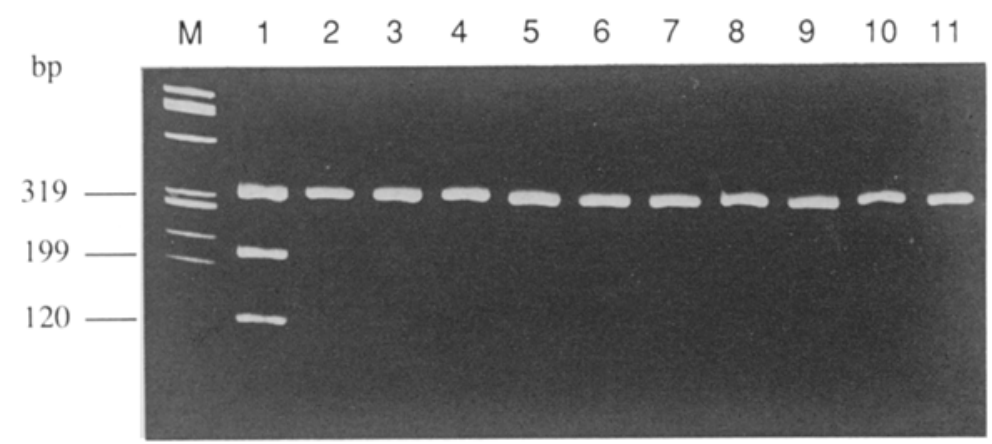

Fig. 2. Polyacrylamide gel analysis of amplified exon 17 after digestion with $B c /$ I. Lane 1 , a sample from a case of early-onset FAD with a $\mathrm{Val} \rightarrow$ Ile mutation at codon 717 (generous gift of Dr. S. Naruse and Prof. S. Tsuji, Department of Neurology, Brain Research Institute, Niigata University) as a positive control for the restriction enzyme reaction; from lane 2 to lane 11 , samples from schizophrenic subjects. DNA from 39 unrelated schizophrenics remains uncut. $\phi \mathrm{X} 174 /$ HaeIII digest was used as a marker to estimate fragment size (lane $\mathbf{M}$ ). 


\section{DISCUSSION}

The detection of a point mutation on APP gene in a case of chronic schizophrenia described by Jones et al. (1992) is interesting because there have never been a solid molecular biological evidence to explain the genetic basis for schizophrenia. To re-evaluate the significance of this mutation, further screenings were promptly conducted. Mant et al. (1992) found no evidence for a mutation on exon 17 of APP gene using SSCP analysis. Carter et al. (1993) and Coon et al. (1993) reported absence of a $\mathrm{C}$ to $\mathrm{T}$ nucleotide substitution at codon 713 by the use of PCR in 104 and 86 unrelated schizophrenics, respectively.

In this study, none of our Japanese subjects had either of these two kinds of mutations. Putting the findings by other investigators cited above together with our findings, the frequency of having these kinds of mutations among schizophrenics is estimated to be very low.

Our findings support the hypothesis that the case of a mutation at codon 713 of APP gene is a rare non-pathogenic variant of no medical importance as Jones et al. (1992) initially implied. It is unlikely that the sequence variants such as at codon 713 or 717 of APP gene have any relation with the genetic predisposition to schizophrenia.

\section{REFERENCES}

Balbin M, Abrahamson M, Gustafson L, Nilsson K, Brun A, Grubb A (1992): A novel mutation in the $\beta$-protein coding region of the amyloid $\beta$-protein precursor (APP) gene. Hum Genet 89: $580-582$

Carter D, Campion D, D'Amato Th, Jay M, Brice A, Bellis M, Mallet J, Agid Y (1993); No mutation in codon 713 of the amyloid precursor gene in schizophrenic patients. Hum Mol Genet 2: 321

Chartier-Harlin MC, Crawford F, Houlden H, Warren A, Hughes D, Fidani L, Goate A, Rossor M, Roques P, Hardy J, Mullan M (1992): Earlymonset Alzheimer's disease caused by mutations at codon 717 of the $\beta$-amyloid precursor protein (APP) gene. Nature 353: 844-846

Coon H, Hoff M, Holik J, Delisi LE, Crowe T, Freedman R, Shields G, Boccio AM, Lerman M, Gershon ES, Gejman PV, Leppert M, Byerley W (1993): C to T nucleotide substitution in codon 713 of amyloid precursor protein gene not found in 86 unrelated schizophrenics from multiplex families. Am J Med Genet 48: 36-39

Goate A, Chartier-Harlin MC, Mullan M, Brown J, Crawford F, Fidani L, Giuffra L, Haynes A, Irving N, James L, Mant R, Newton P, Rooke K, Roques P, Talbot C, Pericak-Vance M, Roses A, Williamson R, Rossor M, Owen M, Hardy J (1991): Segregation of a missense mutation in the amyloid precursor protein gene with familial Alzheimer's disease. Nature 349: 704 706

Hendriks L, Van Duijn CM, Cras P, Cruts M, Van Hul W, Van Harskamp F, Warren A, McInnis MG, Antonarakis SE, Martin JJ, Hofman A, Van Broeckhoven C (1992): Presenile dementia and cerebral haemorrhage linked to a mutation at codon 692 of the $\beta$-amyloid precursor protein gene. Nature Genet $1: 218-221$

Jones CT, Morris S, Yates CM, Moffoot A, Sharpe C, Brock DJH, St Clair D (1992): Mutation 
in codon 713 of the $\beta$ amyloid precursor protein gene presenting with schizophrenia. Nature. Genet 1: 306-309

Mant R, Asherson P, Gill M, McGuffin P, Owen M (1992): Schizophrenia scepticism. Nature Genet 2: 12

Mullan M, Crawford F, Axelman K, Houlden H, Lilius L, Winblad B, Lannfelt L (1992): A pathogenic mutation for probable Alzheimer's disease in the APP gene at the N-terminus of $\beta$ amyloid. Nature Genet 1: 345-347

Murrell J, Farlow M, Ghetti B, Benson MD (1992): A mutation in the amyloid precursor protein associated with hereditary Alzheimer's disease. Science 254: 97-99

Naruse S, Igarashi S, Kobayashi H, Aoki K, Inuzuka T, Kaneko K, Shimizu T, Iihara K, Kojima T, Miyatake T, Tsuji S (1991): Mis-sense mutation Val $\rightarrow$ Ile in exon 17 of amyloid precursor protein gene in Japanese familial Alzheimer's disease. Lancet 337: 978-979 